TE DEUM: Jurnal Teologi dan Pengembangan Pelayanan

Volume 10, Nomor 2 (Juni 2021): 255-278

ISSN 2252-3871 (print), 2746-7619 (online)

http://ojs.sttsappi.ac.id/index.php/tedeum/index

DOI: https://doi.org/10.51828/td.v10i2.33

\begin{tabular}{|l|l|l|}
\hline Submitted: $12-12-2020$ & Accepted: 27-5-2021 & Published: 25-6-2021
\end{tabular}

\title{
PERANAN SPIRITUALITAS MISIONER TERHADAP PELAYANAN JEMAAT GKI PAULUS JAYAPURA
}

\author{
Julita Anastasya Rieuwpassa \\ Mahasiswi Pascasarjana ST'T Cipanas \\ anastasya_rimpassa@yahoo.co.id
}

\begin{abstract}
The main problem in this paper is how to develop and actualize missionary spirituality in the implementation of services in the GKI Paulus Jayapura congregation, so that things that become obstacles in the implementation of services can be properly addressed. The results of the literature study show that the congregation needs to develop and actualize missionary spirituality in carrying out its ministry in daily life. Recognizing the need for every member of the congregation to have and develop missionary spirituality in the ministry, it is necessary to make an alternative effort in the form of coaching and teaching in order to increase each member's understanding of missionary spirituality so that an ideal service can be created.The method used in this research is a qualitative method with a descriptive approach. By using this method, a systematic description of the condition of the GKI Paulus Jayapura congregation can be obtained in terms of understanding and the processes that are taking place, in accordance with the observations and research that have been carried out and can describe the problems at hand.
\end{abstract}

Key words: spirituality, missionary, GKI Paulus Jayapura.

\section{ABSTRAK}

Persoalan pokok dalam tulisan ini yaitu bagaimana upaya mengembangkan dan mengaktualisasikan spiritualitas misioner dalam pelaksanaan pelayanan di jemaat GKI Paulus Jayapura, sehingga hal-hal yang menjadi penghambat dalam pelaksanaan pelayanan dapat diatasi dengan semestinya. Hasilnya menunjukkan bahwa jemaat perlu untuk mengembangkan dan mengaktualisasikan spiritualitas misioner dalam melaksanakan pelayanannya 
dalam kehidupan sehari-hari. Dengan menyadari perlunya setiap anggota jemaat untuk memiliki dan mengembangkan spiritualitas misioner dalam pelayanan, maka perlu diusahakan suatu upaya alternatif berupa pembinaan dan pengajaran agar dapat meningkatkan pemahaman setiap anggota jemaat akan spiritualitas misioner sehingga bisa tercipta pelayanan yang ideal. Metode yang dipakai dalam penelitian ini adalah metode kualitatif dengan pendekatan deskriptif. Dengan menggunakan metode ini, maka dapat diperoleh gambaran secara sistematis tentang keadaan jemaat GKI Paulus Jayapura dalam hal pemahaman serta proses-proses yang berlangsung, sesuai dengan pengamatan dan penelitian yang telah dilakukan dan dapat menguraikan masalah yang dihadapi.

Kata-kata kunci: spiritualitas, misioner, GKI Paulus Jayapura.

\section{PENDAHULUAN}

Gereja adalah persekutuan orang yang percaya dan mendengar panggilan Yesus Kristus serta menyerahkan dirinya dan hidup dalam persekutuan dengan Allah Bapa, Kristus dan Roh Kudus, dilain pihak gereja adalah institusi masyarakat yang menjadi tanda Kerajaan Allah di dunia, sehingga orang-orang dalam gereja adalah mereka yang percaya kepada Kristus dan hidup menurut hukum Kristus. Sebagai umat Allah, orang-orang di dalam gereja menerima berbagai karunia oleh Allah dan yang berada dalam konteks masyarakat, bangsa dan negara. Krisis multidimensi yang masih dirasakan pada saat ini sangat membutuhkan sumbangsih dari seluruh komponen masyarakat untuk menyikapinya secara bijak. Gereja sebagai bagian dari keseluruhan komponen masyarakat juga terpanggil untuk menampakkan peran dan keterlibatannya yang nyata dalam upaya menghadapi krisis global pada saat ini. Gereja memiliki tanggung jawab untuk berjuang melayani dan memperbaiki setiap kondisi negatif yang sedang terjadi pada saat ini.

Gereja adalah orang-orang yang ditugaskan untuk melanjutkan karya dan misi-Nya. Setiap anggota jemaat perlu untuk dirangkul, didampingi dan dibina karena anggota jemaat memegang peranan penting dalam praktek pelaksanaan misi. Gereja pada saat ini harus dilihat sebagai persekutuan atau komunitas orang percaya dengan semangat dalam pelayanan. Gereja pada hakikatnya datang bukan untuk dilayani melainkan datang untuk melayani. ${ }^{1}$ Sementara itu di tengah-tengah kehidupan yang selalu berubah, gereja dituntut untuk terus-menerus beradaptasi. Hal ini berarti gereja harus

1J.L. Ch. Abineno, Diaken (Jakarta: BPK Gunung Mulia, 1994), 4. 
berperan secara konstruktif untuk terus membimbing setiap anggota jemaat. Praktik kegiatan pelayanan di gereja harus memiliki kaitan terhadap konteks yang nyata dan relevan dengan kehidupan dan persoalan jemaat baik dalam kehidupan pribadi maupun dalam kehidupan bermasyarakat. Dalam melaksanakan pelayanan, sangat dibutuhkan pemahaman, metode dan motivasi yang benar agar pelayanan yang dijalankan dapat menjadi suatu pelayanan yang ideal dan dapat memberikan dampak bagi kehidupan setiap anggota jemaat. Hal ini berarti ketika setiap orang melaksanakan pelayanan dan mengalami perubahan yang luar biasa, maka pada akhirnya akan berpengaruh pada jiwanya dan kemudian bisa terekspresikan dengan rasa patuh, keyakinan yang meningkat dan rasa takut.

Masyarakat merupakan habitat dan konteks hidup yang integral dengan kehidupan gereja. Gereja dipanggil Allah untuk berperan serta secara kreatif dan konstruktif di dalam masyarakat dan pada pihak lain masyarakat dengan nilai-nilai budaya, pandangan hidup dan keunikannya akan memengaruhi kehidupan gereja. Unsur yang paling penting dalam keagamaan adalah spiritualitas dalam artian kehidupan kejiwaan atau kerohanian seseorang. Dalam kamus Oxford Advance Learner's yang dituliskan oleh Hornby, spiritualitas didefinisikan sebagai, "the quality of being concerned with religion or the buman spirit" (kualitas yang terkait dengan agama atau jiwa manusia). ${ }^{2}$ Aumann berpendapat bahwa spiritualitas merujuk pada nilai-nilai etik atau religius yang mewujud sebagai suatu sikap hidup atau suatu daya kekuatan yang menggerakkan tindakan seseorang. ${ }^{3}$ Schneiders menyatakan bahwa spiritualitas sebagai suatu pengalaman yang mengarahkan secara sadar kepada pengintegrasian kehidupan seorang pribadi dalam arti yang dengannya umat kembali pada sumber iman mereka yang tekstual untuk tiba pada suatu pengalaman yang mengutuhkan kehidupan. ${ }^{4}$

Spiritualitas misioner adalah spiritualitas yang dianut oleh setiap orang yang menyerahkan seluruh hidupnya untuk menjadi hamba atau pelayan Tuhan yang menemukan dalam dirinya suatu panggilan misioner khusus. Bevans mengungkapkan bahwa spiritualitas misioner merupakan spiritualitas yang kontekstual, ${ }^{5}$ artinya spiritualitas misioner ini

2A. S. Hornby, Oxford Advanced Learner's Dictionary: International Student's Edition (Oxford: Oxford University, 2010), 1435.

3Jordan Aumann, Spiritual Theology (London: Sheed \& Ward, 1980), 17.

"Sandra M. Schneiders, "Spirituality in the Academy," Theological Studies 50, no. 4 (1989): 684, https://doi.org/10.1177/004056398905000403.

5Stephen Bevans, "Towards a Mission Spirituality," n.d. 
bergantung kepada setiap usaha dalam memahami konteks kehidupan manusia secara luas dalam dimensi budaya, agama, sosial, ekonomi dan politik dalam hubungan dengan situasi menyeluruh dengan tujuan agar pemberitaan Injil dapat dilakukan dengan baik dan dipahami secara tepat oleh setiap orang yang hidup dalam konteks tersebut. Aguado juga mengungkapkan bahwa spiritualitas misioner adalah spiritualitas yang bersifat transformatif yang berarti suatu perjalanan yang melibatkan proses pertobatan permanen, perubahan pikiran dan hati menuju kepenuhan hidup dalam Kristus. ${ }^{6}$

Tujuan terpenting dari spiritualitas misioner adalah agar ciri-ciri Kristus terpancar, dinyatakan dan direfleksikan di dalam segala aktivitas setiap hari, baik dalam berpikir, berkata-kata maupun berperilaku dalam kehidupan saat ini, juga bagaimana seseorang memiliki dan memberlakukan nilai-nilai dari spiritualitas misioner merupakan sebuah proses yang harus dijalani seiring dengan pertumbuhan dan perkembangan kepribadian seseorang. Masalahnya bukan menyangkut teknik-teknik yang disampaikan, tetapi menyangkut bagaimana menghidupi panggilan missioner dengan melibatkan diri dalam kegiatan penginjilan secara langsung, mewartakan Injil dan berjuang untuk membentuk komunitas-komunitas Kristen. Panggilan misioner ini biasanya mengikat seseorang secara total dan menjadikannya sebagai suatu pilihan hidup.

Dalam kehidupan modern, gereja seolah kehilangan eksistensinya. Manusia dengan gaya hidup yang sudah sedemikian parah dan jauh dari nilai-nilai agama membutuhkan spiritualitas sebagai motivasi dalam upaya mereka menjalani kehidupannya. Keadaan ini menuntut gereja dalam pengertian yang tidak hanya dibatasi oleh doktrin-doktrin yang kaku dan formalitas yang birokratis dan juga kering dari spiritualisme.

Salah satu indikator pelayanan gereja adalah adanya gereja yang bertumbuh dan berkembang. Menjadi suatu gereja yang bertumbuh dan berkembang adalah dampak dari pelayanan ideal yang diterapkan di gereja. Gereja harus menjadi sebuah tempat di mana jemaat terlibat dalam kehidupan di dalam relasinya dengan Allah dalam Kristus dan manusia. Di era globalisasi pada saat ini, pelayanan gereja mengalami banyak tantangan dan godaan yang membuat semangat dan kualitas pelayanan semakin menurun. Akibatnya pelayanan dilaksanakan hanya sebagai suatu kewajiban atau formalitas belaka atau hanya sebagai pemenuhan kebutuhan pelayanan.

${ }^{6}$ Maria A. Aguado, "Mission Spirituality and Care for Creation: An Introduction," International Review of Mission, 2010, 175-79. 
Dalam situasi seperti ini yang menjadi pertanyaan adalah: "Apakah pelayanan yang diterapkan gereja juga diiringi denganpeningkatan spiritualitas dari jemaatnya?".

Jemaat GKI Paulus adalah salah satu jemaat yang ada di lingkungan Gereja Kristen Injili di Tanah Papua. GKI Paulus memahami pandangan tentang arti gereja di pusatkan pada jemaat yang bersekutu, bersaksi dan melayani. Sebagai jemaat yang menganut paham ini, maka jemaat GKI Paulus perlu menampakkan keberadaannya yang mampu menjadi teladan bagi jemaat yang lain. Apabila diselaraskan dalam realitas yang ada di tengah-tengah kehidupan berjemaat, maka setiap orang harus memiliki pertumbuhan spiritualitas yang benar, agar jemaat semakin bersemangat dan memiliki motivasi yang benar dalam menghayati panggilannya untuk melaksanakan pelayanan. Jika memiliki pemahaman spiritualitas misioner yang benar dan mendalam maka hal ini dapat menempatkan seseorang dalam relasi dengan Allah dan sesamadengan harapan pemahaman tersebut dapat diwujudkan dalam aktifitasnya setiap hari dan juga dalam aspek pelayanan, karena spiritualitas misioner berperan penting untuk menuntun setiap manusia dalam menjalani kehidupannya sehari-hari. Spiritualitas inilah yang mendorong dan memotivasi sehingga menghasilkan kualitas hidup yang dapat menandakan hubungannya secara personal dengan Tuhan yang terlihat dalam bentuk tindakan yang nyata.

Di dalam penyusunan tulisan ini, dibutuhkan data yang akurat, baik berupa data primer maupun data sekunder. Dalam menyelesaikan suatu masalah diperlukan suatu metode yang harus sesuai dengan permasalahan yang akan dibahas. Dengan metode yang telah ditentukan lebih dulu, diharapkan dapat memberikan hasil yang baik serta dapat dipertanggungjawabkan secara ilmiah. Dengan cara ilmiah, diharapkan data yang akan didapatkan adalah data yang objektif, valid dan reliable.

\section{METODE PENELITIAN}

Metode yang dipakai dalam penelitian ini adalah metode kualitatif dengan pendekatan deskriptif. Metode kualitatif artinya penelitian harus menggunakan diri mereka sebagai instrumen, mengikuti asumsi-asumsi kultural, sekaligus mengikuti data-data yang ada. Untuk mencapai wawasan-wawasan imajinatif ke dalam dunia sosial informan, maka 
peneliti diharapkan fleksibel dan refleksi, tetapi juga tetap mengambil suatu jarak tertentu. ${ }^{7}$

Pada penelitian ini peneliti membuat suatu gambaran kompleks, meneliti kata-kata, laporan terperinci dari pandangan responden dan melakukan studi pada situasi yang alami. Dengan menggunakan metode ini, maka dapat diperoleh gambaran secara sistematis tentang keadaan jemaat GKI Paulus Jayapura dalam hal pemahaman serta proses-proses yangberlangsung, sesuai dengan pengamatan dan penelitian yang telah dilakukan dan dapat menguraikan masalah yang dihadapi. Penelitian ini juga mendeskripsikan suatu keadaan, melukiskan dan menggambarkan sejauh mana jemaat GKI Paulus Jayapura dapat memahami dengan benar tentang spiritualitas misioner. Peneliti melakukan kegiatan penelitian dengan terlibat langsung dalam anggota jemaat dan bersama-sama dalam melihat persoalan terkait penulisan ini, kemudian menganalisis hal-hal yang dilihat dan didengar dari anggota jemaat kemudian memaparkan serta menggambarkan, sehingga tampak dengan jelas dan secara terperinci dalam hasil penelitian. Wawancara mendalam yang dilakukan secara bebas memungkinkan para informan memberikan pendapatnya sesuai dengan perspektif mereka sendiri. Dalam penelitian kualitatif, peneliti berbicara langsung dan mengobservasi beberapa orang dan melakukan interaksi untuk mempelajari latar belakang, kebiasaan, perilaku dan ciri-ciri fisik dan mental orang yang diteliti. Metode yang digunakan dalam pengumpulan data biasanya pengamatan langsung, wawancara serta studi dokumen. Penelitian ini digunakan untuk mengetahui makna yang tersembunyi, memahami interaksi sosial, mengembangkan teori, memastikan kebenaran data dan meneliti sejarahperkembangan. Mengingat bahwa penelitian ini bertujuan untuk memahami dan memaknai berbagai fenomena yang ada atau yang terjadi dalam kenyataan sebagai ciri khas penelitian kualitatif. Capaian alam penelitian kualitatif adalah mendapat temuan berupa kesimpulan deskripsi atau gambaran suatu obyek yang sebelumnya belum jelas menjadi jelas.

\section{HASIL DAN PEMBAHASAN}

\section{SPIRITUALITAS}

Setiap orang memiliki kepercayaan, keyakinan, dan pandangan pribadi yang berasal dari agama, budaya, adat-istiadat serta ilmu

${ }^{7}$ Lexi J. Moleong, Metodologi Penelitian Kualitatif (Bandung: Remaja Karya, 1989), 11. 
pengetahuan yang didapatnya. Nilai-nilai kepercayaan tersebut perlu dimiliki karena akan menjadi pedoman hidup serta acuan dalam membentuk sifat perilaku masing-masing. Spiritualitas merupakan salah satu bagian dari kekuatan karakter individu, kekuatan karakter yang merupakan bagian positif yang ditampilkan melalui pikiran, perasaan dan perilaku seseorang. Spiritualitas adalah kenyataan konkret hidup yang mencakup keyakinan iman, keutamaan beserta perwujudannya. ${ }^{8}$ Definisi ini memberikan penjelasan bahwa spiritualitas bukanlah sesuatu yang abstrak, akan tetapi sesuatu yang nyata supaya dapat dilihat realitasnya dalam sikap dan tindakan hidup sehari-hari. Seseorang yang memiliki iman yang teguh dan kuat akan terlihat dari perilaku dan tindakannya dalam kehidupan bermasyarakat. Spiritualitas dan agama seharusnya bisa dibedakan. Ibadah di depan altar rumah ibadah belum tentu mencerminkan spiritualitas seseorang. Agama sering dikenal melalui simbol dan cara ibadah dari seseorang. Sedangkan spiritualitas dikenal dari sikap dalam kehidupan sekuler. Setiap orang bisa melihat agama seseorang melalui kebiasaan ibadah yang dilakukan, sementara spiritualitas dan praktik imannya dilihat dari kehidupan mereka.

Gagasan spiritualitas juga menyingkapkan bagaimana manusia melihat dan mengalami hidup spiritual mereka di dalam kehidupan setiap hari. Dalam spiritualitas, aspek transformatif dari spiritualitas bukan hanya informatif, melainkan juga kemampuan untuk membuat perbedaan antara menilai, melihat secara kritis pengalaman aktual sehubungan dengan nilainilai yang ada. Gagasan spiritualitas adalah segala sesuatu tentang upaya manusia membahasakan pengalaman iman mereka dengan menggunakan bahasa religius dan tradisi yang juga sangat berhubungan dengan keberadaan seseorang yang berada di dalam relasi yang benar dengan Allah, sesama dan ciptaan yang lain. Pemahaman yang dimaksudkan disini bukan berbicara tentang apa yang terjadi, melainkan apa yang seharusnya terjadi. Spiritualitas juga merupakan bagian dari ekspresi kepedulian utama manusia yang dapat mencakup aspek formatif-individual (doa, kesalehan, pengabdian dan amal) dan aspek integratif-sosial (ibadah, pelayanan, komunikasi dan pelayanan kepada dunia). ${ }^{9}$

Duquoc menyimpulkan bahwa spiritualitas adalah pengalaman religius yang dihasilkan oleh proses sosial disekitarnya. Robert menyatakan

8"Konferensi Pemimpin Tarekat Religius Indonesia," in Spiritualitas Pelayanan (Jakarta: Hasil Sidang Pleno KOPTARI, 1987), 4.

9Simon Rachmadi, Reformed Spirituality in Java (Proefschrift) (Amsterdam: Vrije Universiteit, 2017), 23. 
bahwa spiritualitas adalah pengalaman emosi manusia. Pengalaman spiritual adalah pengalaman manusia tentang hal-hal tertentu yang diungkapkan dengan tindakan religius. Puncak-puncak pengalaman spiritual seperti harapan, damai dan rasa syukur dialami ketika emosi-emosi ini menjadi konsen psikologis yang intens. ${ }^{10}$ Spiritualitas merupakan totalitas keberadaan manusia yang menyatakan diri di dalam cara-cara hidup, model dalam berpikir, pola tindakan dan tingkah laku serta sikap manusia.

\section{SPIRITUALITAS DALAM KITAB SUCI}

Kehidupan spiritualitas setiap orang percaya didasari oleh iman yang tertuju kepada Yesus Kristus. Dengan percaya dan beriman kepada Yesus Kristus maka mereka menerima Karunia Roh yaitu Roh Kudus yang tinggal di dalam kehidupan mereka. Dengan adanya karunia Roh yang diterima dan tinggal di dalam hidup orang-orang percaya, maka kehidupan mereka yang lama diperbaharui, menjadi manusia baru (Ef. 4:17-32). Mereka memiliki hidup yang baru yang berada dalam kasih Allah (1Kor. 13).

Spiritualitas Kristen merupakan perjumpaan yang menghidupkan dengan Yesus Kristus dan Roh. Piet Go menyatakan bahwa spiritualitas harus dikaitkan dengan Roh Allah sebagai hidup di dalam Roh. ${ }^{11}$ Martasudjita juga menegaskan bahwa spiritualitas menunjuk kepada bentuk kehidupan rohani yang dilandasi oleh bimbingan Roh Kudus. ${ }^{12}$ Dalam Ensiklopedia Gereja Katolik III, Heuken mengatakan bahwa spiritualitas merupakan hidup yang berdasarkan kepada Roh Kudus dan usaha mengintegrasikan segala aspek kehidupan ke dalam cara hidup yang berpegang kepada iman akan Yesus Kristus serta pengalaman iman Kristiani dalam situasi konkret setiap individu. Iman, pengharapan dan kasih merupakan tanda nyata bahwa setiap orang memiliki spiritualitas di dalam hidupnya. Hal tersebut berdasarkan pada iman kepada Yesus melalui perbuatan dan pengalaman iman dalam kehidupan setiap hari. ${ }^{13}$ Setiap orang yang hidup dengan memiliki spiritualitas Kristen bersedia dituntun dan mendengarkan bimbingan Roh Kudus. Hal ini memberikan pengaruh

10J.B. Banawiratma and Hendri M. Sendjaja, Spiritualitas Dari Berbagai Tradisi (Yogyakarta: Kanisius, 2017), 24.

11Piet Go, Bahan Pengembangan Kerasulan Awam (Jakarta: PT Gramedia, 1994), 18.

${ }^{12}$ Emanuel Martasudjita, Kompendium Tentang Prodiakon (Yogyakarta: Kanisius, 2010), 27.

${ }^{13}$ Adolf Heuken, Spiritualitas Kristiani (Jakarta: Yayasan Cipta Loka Caraka, 2002), 106. 
bagi mereka untuk dapat mengendalikan setiap tindakan yang mereka lakukan.

Dalam Perjanjian Lama kata Roh sering muncul sebagai Ruakh. ${ }^{14}$ Istilah Ruakh ditekankan pada pusat hidup manusia yaitu hubungan antara manusia dengan Tuhan. Ruakh dipahami sebagai hubungannya dengan Tuhan. Manusia sering disebut makhluk rohani, tetapiunsur konstitutifnya adalah Roh dan tubuh. Ruakh manusia merupakan representasi ketergantungan hidup manusia dan relasi dinamisnya dengan Allah. Roh Kudus diberikan kepada semua orang percaya dan memberi mereka kuasa agar menjadi saksi Kristus di mana pun mereka berada di dunia (Kis. 1:8), sampai ke ujung bumi (Mat. 24:14). ${ }^{15}$ Roh di lukiskan sebagai nafas Allah yang memberi hidup kepada apa yang diciptakan-Nya dan ketika Roh ditarik kembali oleh Allah, maka ciptaan itu kembali menjadi debu tanah (Kej. 2:7; Mzm. 104:29-30). Dengan demikian kelanjutan hidup manusia tergantung pada kehadiran Roh Allah di dalam diri setiap manusia (Kej. 6:13). Dapat dikatakan bahwa manusia diciptakan dan terus hidup oleh karena Roh Allah (Ayb. 33:4). Manusia memperoleh hidup baru dari pada Roh (Yeh. 37:9-14). ${ }^{16}$ Roh Allah yang tinggal di dalam manusia menjadi suatu daya penggerak untuk menjalankan dan melaksanakan perintah Allah. Roh Allah mengarahkan hidup manusia menjadi lebih bersemangat dan teguh dalam iman. Spiritualitas yang dimaksudkan disini ialah Roh Allah yang menggerakkan, memanggil, menjiwai, menuntun dan mengarahkan manusia kepada kepenuhan panggilan dan kewajibannya. Manusia yang digerakkan oleh Roh Allah akan diberikan kemampuan dan kekuatan untuk menjalankan kewajiban dan panggilan hidupnya.

Sejak berdirinya kekristenan sampai kini nyata bahwa untuk menjadi orang percaya tidak hanya tindakan instan sekali selamanya tetapi juga oleh pekerjaan Roh Kudus yang menghasilkan pertobatan dan lahir baru. Spiritualitas itu ibarat benih yang memiliki potensi untuk tumbuh dan berkembang dalam pengenalan akan Kristus sampai semua mencapai kesatuan iman dan pengetahuan yang benar tentang Anak Allah, kedewasaan penuh dan tingkat pertumbuhan rohani yang sesuai dengan kepenuhan Kristus (Ef. 4:13). Dinamika atau penggerak kehidupan spiritualitas Kristen oleh Paulus diuraikan berkenaan langsung dengan peranan Roh Kudus dalam perkembangan watak Kristiani. Roh yang

${ }^{14}$ S. Tengström and J. Fabry, Theological Dictionary of the Old Testament. (Grand Rapids: Eerdmans XIII, 2006), 372.

15J. Ruck, Jemaat Misioner (Jakarta: Yayasan Komunikasi Bina Kasih, 2011), 185.

16B. Milne, Mengenali Kebenaran (Jakarta: BPK Gunung Mulia, 2002), 243. 
melampaui batas-batas alamiah akan mendorong dan mengarahkan pada pertumbuhan rohani yang dinamis dan makin dewasa dalam pengenalan akan Yesus Kristus. Paulus sadar bahwa untuk perkembangan watak spiritual membutuhkan dorongan adikodrati dan hal ini tampak jelas dalam penggunaan istilah buah berbentuk tunggal (Gal. 5:22) untuk memperlihatkan bahwa semua sifat yang disebutkannya merupakan suatu keseluruhan yang padu yaitu watak yang dipenuhi Roh. ${ }^{17}$

Dengan demikian dapat disimpulkan bahwa peranan Roh Kudus sangat penting dalam menggerakkan kehidupan spiritualitas Kristen. Oleh sebab itu, haruslah setiap orang percaya meminta bimbingan dan pendampingan dari Roh Kudus agar di mampukan untuk memahami dan memiliki pertumbuhan spiritualitas yang tepat. Pekerjaan Roh Kudus itu oleh Tuhan Yesus digambarkan seperti angin yang bertiup ke mana saja ia mau, namun dampaknya terlihat nyata (Yoh. 3:8). Apabila Roh Kudus memenuhi hati setiap orang yang percaya dan lahir kembali maka dampaknya pasti nyata. Dampak yang dimaksud adalah perubahan seluruh aspek kehidupan yang dikerjakan oleh Roh Kudus dalam diri setiap orang yang percaya dan taat kepada Tuhan.

Hidup sebagai orang Kristen adalah hidup yang dipenuhi oleh Roh Kudus, diperbaharui dan dipimpin oleh Roh Kudus secara terus-menerus. Roh Kudus menjadi daya kekuatan yang menggerakkan, mendorong, memotivasi, menyemangati, meneguhkan, melindungi, membimbing serta menuntun setiap manusia untuk tetap setia menjadi pengikut-Nya. Spiritualitas dikerjakan oleh Roh Kudus. Kehidupan rohani yang diperbaharui dalam diri orang Kristen adalah efek langsung dari Roh yang memberi hidup dan juga Roh yang berdiam di dalam diri setiap manusia. Spiritualitas merupakan semangat yang berasal dari Allah yang menyelimuti hidup setiap orang sehingga dalam segala tindakan yang dilakukannya dapat terlihat bahwa Roh Allah yang berkarya dan diwujudkan dalam tindakan nyata.

\section{SPIRITUALITAS MISIONER}

Salah satu elemen penting dalam diri manusia sebagai gambar dan rupa Allah adalah otoritas mereka atas bumi. Walaupun manusia sudah jatuh ke dalam dosa dan hubungan mereka mengalami perubahan (Kej. 3:15-19), namun mereka tetaplah gambar dan rupa Allah yang diberi 98.

17Donald Guthrie, Teologi Perjanjian Baru (Jakarta: BPK Gunung Mulia, 1993), 197- 
mandat untuk menguasai bumi (Kej. 9:6; Mzm. 8:1-10; Yak. 3:9). Status ini mencakup semua manusia, baik yang percaya kepada Kristus maupun tidak. Dalam konteks yang lebih luas ini, orang Kristen juga harus berperan dalam pelayanan sosial di masyarakat. Orang Kristen harus berbuat baik kepada semua orang (Mat. 5:44-48; Luk. 10:29-37; Gal. 6:10a). Hal ini dilaksanakan tanpa pamrih karena bertumpu pada kerinduan yang berkenan kepada Tuhan dengan melakukan perintah-perintah-Nya. Spiritualitas misioner merupakan spiritualitas yang holistik dan itu merupakan salah satu model dalam bermisi. ${ }^{18}$ Spiritualitas ini menciptakan arah pelayanan yang holistik yang memiliki tujuan untuk memenuhi kebutuhan manusia yang utuh dan memperbaharui/transformasi manusia yang utuh. Hal ini sangat sesuai dengan ajaran dan pola pelayanan yang dilakukan oleh Yesus.

Spiritualitas misioner adalah spiritualitas yang dianut oleh setiap orang yang berkomitmen untuk melibatkan diri dalam pewartaan Injil Kerajaan Allah dan juga yang memiliki motivasi untuk terlibat dalam membangun gereja. Murid-murid diutus untuk melakukan penginjilan sama seperti yang telah dilakukan Yesus, sedangkan dalam pelayanan Yesus, Ia tidak hanyamemberitakan Injil tetapi juga memerhatikan setiap masalahmasalah sosial. Setiap orang yang memahami spiritualitas misioner adalah orang-orang yang selalu menghidupi identitas misioner. Mereka menganut tindakan praktik yang nyata dan menaruh perhatian terhadap masalahmasalah kemiskinan, gender, ketidakadilan sosial, ekonomi, politik dan sebagainya. Spiritualitas ini juga merupakan keyakinan iman, sikap dan keutamaan maupun pilihan serta tindakan yang mendukung keterlibatan setiap jemaat Kristen untuk melayani Kerajaan Allah yang hadir, berada dan tubuh dalam kenyataan sosial masyarakat. ${ }^{19}$ Spiritualitas misioner dapat dimengerti sebagai semangat yang berasal dari Allah untuk melayani Kerajaan Allah yang hadir dalam kenyataan hidup manusia. Dipahami juga dalam konteks transendensi hidup manusia yang memberi makna dan yang sekaligus mengarahkan serta menyatukan seluruh kegiatan hidupnya melalui cinta, pengetahuan dan tindakan.

Spiritualitas ini tidak hanya terbatas pada setiap praktik spiritual saja, tetapi juga terhadap kesadaran yang sepenuhnya akan realitas kehadiran Allah baik di dalam kehidupan pribadi maupun kehidupan bersama dengan orang lain. Seperti di dalam emosional pribadi, sosial, ekonomi, moral,

${ }^{18}$ Yohanes Hasiholan Tampubolon, "Misi Gereja Di Era Kapitalisme Global: Eksplorasi Pelayanan Misi Yesus," Societas Dei: Jurnal Agama Dan Masyarakat 7, no. 2 (October 2020): 203, https://doi.org/10.33550/sd.v7i2.137.

19“Konferensi Pemimpin Tarekat Religius Indonesia." 
profesi, hubungan dengan sesama dan semacamnya tidak dibiarkan lepas dari kesadaran tentang pentingnya spiritualitas misioner. Hal ini didasarkan pada pengakuan yang sepenuhnya bahwa tidak ada satupun bagian kehidupan orang-orang percaya yang boleh terpisah dari kehadiran Allah. Permasalahannya bukan menyangkut teknik yang dijalani, tetapi menyangkut bagaimana menghidupi spiritualitas misioner dalam kehidupan setiap hari. Dalam spiritualitas misioner terdapat keseimbangan antara aksi dan kontemplasi. Penyebaran misi Kristen tidak dapat dijalankan tanpa kontemplasi, begitu pula hidup kontemplasi yang autentik akan menuntun pada keterlibatan misioner. ${ }^{20}$ Bevans mengemukakan bahwa spiritualitas misioner dapat memotivasi tindakan dan juga meningkatkan komitmen dengan selalu mengandalkan kehadiran Roh Allah. Ia juga mengemukakan bahwa spiritualitas tidak berkembang secara abstrak, karena spiritualitas misioner selalu berakar pada keadaan konkret. ${ }^{21}$ Pengulangan penting pada setiap tindakan yang mencerminkan spiritualitas missioner karena tindakan ini dapat menciptakan kebiasaan dalam menghidupi peran dari spiritualitas misioner.

Panggilan misioner dapat dihayati dengan berbagai cara yang berbeda. Ada orang yang mewujudkan panggilan misionernya dalam doa dan kontemplasi serta askese demi perkembangan pewartaan Injil. Begitu pula terdapat bentuk lain untuk menghayati panggilan misioner yaitu dalam usaha animasi misioner. Setiap usaha ini memungkinkan dan memudahkan terjadinya perluasan penyebaran Injil kepada mereka yang belum mengenal Kristus. Contoh penghayatan panggilan yang demikian dapat ditemukan misalnya dalam kegiatan yang bertujuan untuk pengembangan iman yang mampu memprakarsai upaya-upaya sosial dan gerakan spiritual hidup rohani. Ada lagi bentuk lain yaitu dalam wujud keterlibatan langsung dalam karya misioner bagi pewartaan injil di antara orang-orang non-kristiani dan pembangunan/pembentukan komunitas gereja. ${ }^{22}$ Jemaat harus menjadi suatu komunitas Kristen yang mengalami pertumbuhan. Gereja harus tetap memelihara identitasnya sebagai tubuh spiritual Kristus dan nyata dalam masyarakat. Banyak orang Kristen sering kali berasumsi bahwa adanya gedung gereja yang cukup besar dan bagus akan menguatkan persekutuan, pelayanan dan kesaksian serta membantu pertumbuhan iman jemaat. Padahal hal ini bukanlah faktor yang menentukan pertumbuhan iman

\footnotetext{
${ }^{20}$ Paulinus Yan Olla, Menjadi Saksi Kasih (Yogyakarta: Kanisius, 2008), 13.

${ }^{21}$ Bevans, "Towards a Mission Spirituality."

22Olla, Menjadi Saksi Kasih.
} 
jemaat. Setiap orang yang percaya kepada Yesus akan melakukan kehendakNya (Mat. 7:21) dan menghasilkan buah (Yoh. 15:1-17), karena firman-Nya berada di dalam hati mereka (Yoh. 8:31; 15:7). Implikasi kebenaran bagi gereja adalah supaya gereja dimaksudkan untuk bertumbuh secara kualitatif (mutu kehidupan) dan kuantitatif (jumlah) bagi kemuliaan Allah. Kehendak Allah bagi setiap orang percaya adalah pertumbuhan dalam iman sampai mencapai kedewasaan dalam Kristus (Ef. 4:15), untuk menjadi seperti Yesus (Rm. 8:29). Hal ini tidak terjadi secara otomatis, tetapi dengan upaya tertentu (Flp. 2:12-13; 1Tim. 4:7), selagi orang percaya bertekun dalam pengajaran dan persekutuan (Kis. 2:42), menyerahkan diri kepada Allah (Rm. 6:13; 12:1) dan menaati firman-Nya (Yak. 1:22), sehingga tidak menjadi serupa dengan dunia ini, tetapi kehidupannya mengalami transformasi (Rm. 12:2) oleh Roh Allah yang berdiam dalam diri setiap orang percaya (1Kor. 6:19, Gal. 5:22-23). ${ }^{23}$

Panggilan misioner mencakup seluruh dimensi tugas Kristen (Ef. 4:8,12). Setiap anggota jemaat Kristen terpanggil kepada tugas misioner ini. Panggilan misioner merupakan arah pelayanan yang holistik yang memiliki tujuan untuk memenuhi kebutuhan manusia yang utuh dan memperbaharui/transformasi manusia yang utuh. Hal ini sangat sesuai dengan ajaran dan pola pelayanan yang dilakukan oleh Yesus. Tugas misioner yang internal mencakup pelayanan jemaat kepada Tuhan adalah ibadah (melalui doa, pujian, sakramen dan mendengar firman-Nya), pelayanan anggota satu sama lain untuk kepentingan bersama (1 Kor. 12:7; 2 Kor. 8:4), pelayanan mengajar yang melaluinya jemaat yang percaya dan menanamkan norma-norma tradisi rasuli (Kis. 6:4; Rom. 12:7). Ibadah, berbagi dan mengajar sangat penting bagi vitalitas kehidupan spiritual setiap jemaat Kristen. Tugas misioner yang eksternal juga memiliki beberapa komponen. Komponen ini sering digambarkan sebagai misi gereja karena komponen-komponen tersebut mencakup semua hal yang harus dilakukan oleh orang Kristen dan karena itulah mereka diutus ke dunia. Tugas misioner yang dimaksud adalah menjalankan pelayanan kepada orang miskin, janda, yatim, tahanan, tunawisma dan lain-lain (Rm. 12:7-8; Gal. 6:10a) juga setiap jemaat Kristen yang terlibat dalam aktivitas kerukunan demi keadilan sosial dalam masyarakat. Ketika Yesus menjelaskan bahwa Ia datang untuk melayani dan memberikan hidup-Nya sebagai tebusan untuk banyak orang, Ia memaksudkan hal itu sebagai teladan tentang kebesaran untuk kita (Mrk. 10:43-45; Mat. 20:25-28). Ketika terjadi perdebatan

${ }^{23}$ Ruck, Jemaat Misioner. 
mengenai siapa murid yang paling besar, Yesus mengatakan bahwa yang paling besar adalah dia yang melayani. Ia kemudian mengatakan, "Aku ada di tengah-tengah kamu sebagai pelayan" (Luk. 22:24-27). Ketika Yesus membasuh kaki murid-murid-Nya, Ia memaksudkan tindakan itu sebagai hal yang harus diteladani oleh murid-Nya (Yoh. 13:14-17). ${ }^{24}$

\section{UNSUR-UNSUR DALAM SPIRITUALITAS MISIONER}

\section{Berpusat pada Kristus}

Orang Kristen tidak dapat memahami ataupun melaksanakan karya misi kecuali mengarahkannya kepada Kristus sebagai Dia yang diutus untuk memberitakan Injil. Di dalam Filipi 2:1-11, Paulus memberikan gambaran yang sangat jelas mengenai karya Kristus di dalam hal ketaatan-Nya melaksanakan kehendak Bapa. Paulus mengatakan bahwa dalam keadaanNya sebagai manusia, Ia telah merendahkan diri-Nya dan taat sampai mati di kayu salib. ${ }^{25}$ Ketaatan merupakan kunci utama yang harus dimiliki oleh setiap orang percaya, karena Kristus telah menjadi teladan yang paling utama dengan menempatkan diri-Nya untuk senantiasa taat kepada kehendak Bapa-Nya.

Kristus menghabiskan hidup-Nya untuk melayani sesama. Dia menyembuhkan mereka dari penyakit. Dia membuat yang buta melihat, yang tuli mendengar dan yang lumpuh berjalan. Dia memberkati lima roti dan dua ikan serta secara menakjubkan dapat memberi makan 5000 orang (Mat. 14:14-21). Dia mengajarkan bahwa kapan pun kita sebagai orang Kristen mendapati orang kelaparan, kedinginan tanpa pakaian atau kesepian hendaknya membantu mereka sebatas kemampuan.

Perkembangan zaman dan gaya hidup yang semakin berkembang akan sangat memengaruhi kehidupan dan pola pikir manusia, termasuk di dalam kehidupan orang percaya. Akan ada begitu banyak tantangan dan godaan yang bisa menggoncangkan iman dan panggilan orang percaya sebagai murid Kristus. Gereja juga mewartakan Injil kepada dunia dengan kesaksian hidup yang setia kepada Kristus. Menjadi saksi Kristus bukanlah tugas yang mudah karena jemaat harus menyampaikan atau menunjukkan apa yang dialami dan diketahui tentang Kristus kepada orang lain. Dengan demikian dalam situasi apapun, harus tetap berpegang teguh pada Kristus

${ }^{24}$ Ajith Fernando, Allah Tritunggal Dan Misi (Jakarta: Yayasan Komunikasi Bina Kasih, 2008), 41.

25Douglas, Tafsiran Alkitab Masa Kini 3, Matius-Wabyu (Jakarta: Yayasan Komunikasi Bina Kasih, 1982), 646. 
sehingga pada akhirnya nanti ketika diperhadapkan dengan berbagai ujian yang sulit untuk dipahami, jemaat tetap teguh berpegang pada Kristus dalam mengatasi masalah. Dalam Yakobus 5:13-20, Yakobus memanggil orang-orang percaya untuk memiliki hidup yang berpusat pada Kristus di setiap aspek hidup, setiap waktu dan dalam segala keadaan. Ini adalah salah satu implikasi dari kehidupan yang percaya pada Kristus. Kristus haruslah menjadi pusat hidup setiap orang percaya dalam kehidupan pribadi, keluarga, gereja dan masyarakat karena ketika kehidupan yang mereka jalani terpusat pada Kristus maka, akan membuat mereka senantiasa mengutamakan dan mengandalkan-Nya.

\section{Kehadiran Roh Kudus}

Peran Roh Kudus dalam jemaat pada zaman sekarang ini sangat penting dalam memberikan dorongan dan motivasi bagi jemaat untuk memberitakan karya Injil. Dalam kehidupan orang percaya, Roh Kudus memiliki peran penting dalam menumbuhkan kerohanian. Dalam setiap aspek kehidupan, Roh Kudus menjadi sangat sentral. Roh Kudus menolong setiap orang percaya supaya ia dengan penuh kuasa dapat meneruskan kepada orang lain tentang kebenaran yang dipahaminya karena ada karya Roh Kudus (1Kor. 2:1-5; 1Tes. 1:5; Kis. 1:8) dan setiap orang yang percaya kepada Yesus akan diberikan kuasa oleh Roh Kudus untuk dapat bersaksi tentang karya Injil. Jika setiap orang disertai dengan kuasa Roh Kudus maka apa yang dikatakannya memiliki kuasa yang dapat membangun, memotivasi dan memberikan pengajaraan.

Roh Kudus memimpin sesuai kebenaran yang datang dari Allah dan menerapkannya dalam kehidupan setiap manusia. Ketika itu terjadi, maka orang percaya memutuskan untuk mengizinkan Roh Kudus berkuasa dalam hidupnya. Spiritualitas itu nampak ketika orang percaya yang sudah dilahirkan kembali melalui baptisan itu mengizinkan Roh Kudus memimpin dan menguasai hidupnya. Dengan demikian, ketika setiap orang yang membuka hati dan membiarkan Roh Kudus memimpin setiap karya pelayanannya maka yang ia sebarkan adalah kebenaran dari Allah sendiri yang menjadi Sang Kebenaran.

Gereja dan anggota jemaat adalah satu organisme yang saling berkaitan maka perkembangan dan pertumbuhan menjadi suatu ciri khas yang wajib untuk diterapkan. Roh Kudus merupakan dasar yang sangat penting dalam pertumbuhan gereja. Oleh sebab itu tidak akan ada gereja yang bertumbuh tanpa adanya kehadiran Roh Kudus. Karena melalui 
kehadiran Roh Kudus setiap anggota jemaat semakin bertumbuh baik dalam iman maupun kapasitas hidup.

Karya Allah yang menyatakan diri-Nya melalui firman-Nya serta secara khusus melalui Anak-Nya Yesus Kristus itu diterapkan oleh Roh Kudus kepada manusia dalam setiap situasi kehidupan mereka. Peran Roh Kudus diantaranya mengilhamkan firman Allah dan menerapkannya kepada manusia, menyadarkan tentang dosa dan kebutuhan, membuka hati untuk bertobat dan menerima Kristus dalam hati dan kehidupan, menjadikan manusia baru dan komunitas dalam Kristus, memimpin setiap manusia untuk hidup bagi Kristus, dan memberikan kuasa untuk menjadi saksi-Nya. Spiritualitas inilah yang mendorong setiap manusia untuk siap sedia dibentuk dari dalam oleh Roh. Tidaklah mungkin dapat menjadi saksi tentang Kristus tanpa mencerminkan citra-Nya yang dihidupkan kembali di dalam diri manusia dan berkat rahmat serta kekuatan Roh yang mendorong dan memimpin untukmenjadi orang percaya. Dalam Roma 8:16, Paulus menerangkan hal ini seperti berikut "Roh itu bersaksi bersama-sama dengan roh kita, bahwa kita adalah anak-anak Allah". Dalam hal ini, Roh Kuduslah yang mula-mula bekerja (Rm. 8:23). Ia yang menjadi jaminan keselamatan yang telah dijanjikan Allah kepada umat-Nya (2Kor. 1:22; 5:5; Ef. 1:14).

Roh Kudus adalah oknum yang memampukan setiap orang percaya untuk melakukan karya penginjilan dan menjadikan kehidupan rohani semakin berkualitas. Setiap orang yang dipenuhi oleh Roh Kudus dapat dilihat melalui kehidupannya setiap hari yang dapat memberikan dampak pada sekitarnya, menjadi orang yang disegani dan berpengaruh dalam masyarakat.

\section{Motivasi Misioner}

Gereja harus menyadari dengan jelas mengapa mereka terpanggil dalam melaksanakan misi, yaitu karena gereja misioner adalah misi yang ditujukan kepada dunia. Misi bukan urusan gereja sebagai institusi saja, tetapi juga merupakan misi para anggota jemaat di tengah-tengah masyarakat. Jemaat yang memiliki motivasi misioner adalah jemaat yang merendahkan diri dan setia menjadi hamba Allah dalam rangka pelaksanaan misi Kerajaan-Nya dengan tidak menjadikan dirinya sendiri sebagai pusat dan tujuan misi, tetapi menjadikan Kerajaan Allah sebagai arah dan tujuan seluruh aktivitas kehidupan. Memiliki motivasi misioner berarti mendorong keterbukaan terhadap sesama dan dunia ini, terbuka dalam pandangan, penghayatan hidup dan iman akan orang lain. Setiap aspek kehidupannya, 
harus terlihat bahwa Allah yang berkarya dalam hidupnya serta karya Allah itu harus dipahami dengan benar, sehingga semua orang dapat melihatnya dari perilaku dan perbuatannya di tengah-tengah masyarakat. Sebagai orang yang menjalankan pelayanan, jemaat perlu berkembang secara rohani dan memiliki sikap yang berani sehingga dapat membawa setiap orang menjadi semakin beriman dan percaya akan penyertaan Allah dalam hidup mereka. Pewartaan Injil yang dilakukan bukan hanya melalui perkataan saja, melainkan juga melalui tindakan dan seluruh aspek kehidupan. Hendaknya apa yang diajarkan sesuai dengan apa yang dipraktikkan dalam kehidupan sehari-hari yang dijalaninya. ${ }^{26}$

Motivasi misioner juga bertindak dalam memperjuangkan keadilan, kasih, perdamaian dan keutuhan ciptaan tidak hanya di tengah-tengah dunia, tetapi juga di dalam gereja. Gereja hadir sebagai hamba yang terpanggil untuk melayani masyarakat melalui keterlibatan gereja dalam perjuangan menghadirkan setiap tanda Kerajaan Allah. Gereja juga memberi perlindungan dan menyatakan suara penuh harapan bagi masyarakat yang putus asa menghadapi keserakahan, bencana, kebencian, penyakit dan kematian. Setiap tindakan misioner dapat dinyatakan dengan tindakan kasih kepada Tuhan dan sesama, yang disertai dengan kemurnian hati, pola hidup sederhana, ketaatan, kerendahan hati, perbuatan, perkataan serta isi hati yang dinyatakan di dalam integritas moral dan etika dalam kehidupan.

\section{Pelayanan yang Misioner}

Gereja memiliki peranan yang sangat penting bagi pertumbuhan spiritualitas setiap anggota jemaat, karena pertumbuhan iman jemaat diberikan atau difasilitasi oleh gereja. Pelayanan yang dijalankan haruslah memiliki fokus misioner yang bukan hanya menjangkau gereja, tetapi juga lingkungan tempat gereja berada. Sering kali gereja mengabaikan pelayanan diakonia atau pelayanan yang dapat menjangkau masyarakat disekitarnya. Hakikat pelayanan yang dijalankan harus bersifat holistik. Makna dari pelayanan misioner bukanlah hanya dilandasi oleh kepedulian humanistik. Pelayanan ini menyatakan secara utuh kasih Allah kepada manusia. Pelayanan yang dijalankan merupakan kewajiban dalam melaksanakan misi Allah untuk menghadirkan keselamatan di tengah-tengah lingkungan

${ }^{26}$ Lih. Yohanes Hasiholan Tampubolon, "Kontekstualisasi Metodologi Misiologi Paulus Dalam Dunia Kontemporer," Excelsis Deo: Jurnal Teologi, Misiologi, Dan Pendidikan 3, no. 2 (December 31, 2019): 24, https://doi.org/10.51730/ed.v3i2.13. 
masyarakat yang masih terikat kepada ketidakadilan, diskriminasi, penindasan, kekerasan dan lain-lain. Oleh karena itu, pelayanan yang dijalankan harus misioner dengan visi yang jelas dan didasari perencanaan yang matang dalam situasi dan konteks jemaat. Pelayanan harus menjawab setiap kebutuhan pergumulan jemaat dan masyarakat. Program pelayanan gerejawi merupakan respons dan tanggungjawab gereja untuk terlibat dalam persoalan-persoalan setiap jemaat dan masyarakat. Prioritas tugas pelayanan gerejawi adalah menjawab kebutuhan konkret sehingga melalui program pelayanan setiap jemaat dan anggota masyarakat dapat merasakan dampaknya. Strategi dan metode harus tepat sehingga setiap program pelayanan yang ditetapkan oleh gereja dilengkapi dengan cara pencapaian yang efektif dan efisien. Pelayanan misioner merupakan media pembinaan, pelatihan, pengembangan karakter dan pendalaman spiritualitas agar setiap jemaat dimampukan untuk melayani di lingkungan gereja dan masyarakat.

Gereja diperhadapkan kepada pelayanan yang dapat menyentuh seluruh aspek kehidupan manusia seutuhnya yaitu kehadiran gereja dalam pelayanan misioner yang seharusnya dapat menyentuh aspek jasmani dan rohani, sehingga tidak hanya memikirkan hal jasmani tanpa mempedulikan aspek rohani dan sebaliknya. Sebenarnya alasan utama perlunya pengembangan pelayanan yang melibatkan seluruh komponen gereja termasuk jemaat, terletak pada ruang lingkup pelayanan gereja itu sendiri. Gereja terpanggil untuk memberkati dunia dan masyarakatnya secara utuh, baik secara rohani maupun jasmani. Hal Ini berarti bahwa gereja bertanggungjawab secara luas untuk membawa masyarakat bergerak ke arah yang lebih baik, positif dan berarti. Dengan melihat luasnya ruang lingkup pelayanan gereja ini, maka tidak mungkin untuk menyaksikan bagaimana keseluruhan tugas panggilan itu dapat terlaksana tanpa melibatkan peran serta seluruh jemaat.

Tugas gereja adalah persekutuan, pelayanan dan kesaksian yang disebut dengan tri tugas panggilan gereja, yang dinyatakan di dalam persekutuan. Gereja dipanggil Allah melalui karya Yesus Kristus untuk menjadi satu persekutuan dalam tubuh Kristus untuk melaksanakan pelayanan. Persekutuan setiap orang Kristen yang dipanggil itu diutus-Nya ke dalam dunia untuk memberitakan Injil dalam bentuk pelayanan di tengah jemaat dan masyarakat, serta untuk bersaksi dan mengajarkan bahwa persekutuan orang-orang Kristen yang dipanggil itu diutus-Nya untuk memberitakan kebenaran Injil kepada dunia. Pemberitaan itu dilaksanakan dalam beragam bentuk termasuk pelayanan dalam agama Kristen. 
Dalam menjalankan pelayanan, sangat penting bagi setiap jemaat Kristen untuk terus mengevaluasi pelayanan yang dikerjakan. Karena seringkali jemaat terjebak dalam kondisi pelayanan yang bermotivasi untuk keuntungan diri sendiri. Spiritualitas yang bertumbuh adalah spiritualitas yang bukan hanya sebatas rutinitas saja, tetapi juga yang menyatu dengan seluruh aspek kehidupan. Pelayanan dan spiritualitas selalu memiliki hubungan yang tidak dapat dipisahkan. Untuk bisa melakukan pelayanan yang ideal maka diperlukan spiritualitas misioner yang bisa menjadi pendorong dan penyemangat dalam melaksanakannya.

Bevans mengemukakan bahwa spiritualitas misioner dapat memotivasi tindakan dan juga meningkatkan komitmen. ${ }^{27}$ Perkataan dan tindakan setiap orang yang memahami spiritualitas misioner bukan sebuah tindakan untuk mendapatkan materi, mencari popularitas, mendapatkan kedudukan atau kuasa atau supaya disenangi oleh orang lain melainkan mereka hidup untuk mengejar nilai-nilai misioner dan menjalankan kewajibannya sebagai seorang Kristen. Spiritualitas misioner merupakan spiritualitas yang dapat mendorong, memotivasi seseorang sehingga apa yang diimani berjalan seiring dengan apa yang dilakukan dalam relasinya dengan Tuhan dan masyarakat dalam dunia secara konkret.

Spiritualitas merupakan salah satu faktor yang dapat memengaruhi kualitas hidup setiap anggota jemaat. Semakin tinggi tingkat spiritualitas maka kualitas hidup semakin baik. Spiritualitas dapat memengaruhi kualitas hidup setiap anggota jemaat dengan menurunkan tingkat kesedihan, kemarahan, kecemasan, keraguan dengan meningkatkan harapan, membuat seseorang merasa lebih optimis dalam bertindak. Kematangan hidup rohani sangat berhubungan dengan spiritualitas setiap pribadi. Dasar hidup rohani dan semua bentuk spiritualitas sejati adalah Roh, yaitu Roh Kristus seperti tampak dalam Injil. Orang yang peka akan mengalami buah kehadiran Roh dalam hatinya $\left(\mathrm{Rm}\right.$ 8:16). ${ }^{28}$ Hidup kristiani adalah hidup di dalam Kristus. Spiritualitas misioner mampu membimbing setiap orang ke hidup yang lebih mendalam bersama Kristus dan tumbuh dalam Roh. Spiritualitas misioner pada dasarnya adalah spiritualitas Kristen yang berkomitmen dan melibatkan diri dalam pekerjaan misi. Spiritualitas missioner ini terwujud dalam tindakan yang nyata dan tindakan yang menaruh perhatian terhadap masalah kemiskinan, gender, ketidakadilan sosial, ekonomi, politik dan sebagainya. Bagaimana seseorang hidup secara kristiani, spiritualitas

${ }^{27}$ Bevans, "Towards a Mission Spirituality."

${ }^{28}$ Heuken, Spiritualitas Kristiani. 
misioner hadir sebagai faktor yang menggerakkan kehidupan iman seseorang. Bisa juga diartikan sebagai faktor yang memperdalam iman seseorang menuju kedewasaan.

Semangat spiritualitas misioner sangat perlu untuk diterapkan di antara anggota jemaat, agar mereka memiliki semangat dalam menjalankan pelayanan walaupun sering diperhadapkan dengan tantangan-tantangan di lingkungan masyarakat. Spiritualitas ini secara konkret merupakan suatu cara hidup dari seseorang yang dipanggil dan diutus dalam menjalankan karya misi. Faktor yang mendukung terciptanya spiritualitas misioner ialah kasih kepada Allah, harapan dan janji keselamatan, kasih kepada orang lain serta penyangkalan diri. Menjaga pertumbuhan iman dari setiap jemaat, di sisi lain adalah bantuan yang harus diberikan seperti disaat mereka lemah maka dikuatkan, di saat mereka tersesat maka dibantu untuk menemukan jalan keluar,setiap jemaat memiliki peran sebagai seorang saudara bagi sesama mereka. Serta menjalankan pelayanan kasih yang memenuhi kebutuhan masyarakat, diperlukan sikap rendah hati, peka terhadap kebutuhan orang lain dan prihatin akan hal-hal yang penting bagi orang lain. Semangat spiritualitas misioner dalam pelayanan mampu menjadi model bagi setiap anggota jemaat, agar jemaat menjadi teladan bagi orang lain dalam perkataan, tingkah laku, kasih, kesetiaan dan dalam kesucian. Tidak hanya itu saja bahwa setiap jemaat harus diliputi dengan sifat rendah hati dalam menerapkan pelayanannya.

Pelayanan dimulai dalam gereja yang dalam Kristus merupakan satu tubuh dengan banyak anggota, saling membutuhkan dan melayani (1 Kor. 12:31). Sebagai anggota gereja, jemaat juga ikut dalam setiap proses perkembangan gereja. Semua pihak turut ambil bagian dalam tugas pelayanan yang telah diteladani Yesus sebagai Kepala dari semua anggotaNya. Pelayanan adalah bagian dari partisipasi seseorang dalam menjalankan misi Allah di tengah dunia ini. Pelayanan tidak hanya berfokus kepada struktur atau hierarki gereja, melainkan berfokus kepada tugas utama gereja sebagai alat misi Allah. Perkembangan pelayanan yang dilakukan sebagai bagian dari misi, haruslah menjadi suatu pelayanan yang memperhadapkan jemaat dengan keadaan sekitarnya dan juga kehendak Tuhan. Dalam hal ini, harus ada proses pengajaran dan penggembalaan, sekaligus pembekalan dan pemberdayaan, agar bisa tercipta pelayanan yang ideal. Hal ini sangat menekankan keutuhan gereja sebagai tubuh Kristus, di mana setiap anggota memiliki peranan khusus.

Ketua Sinode, Pendeta jemaat, Guru sekolah minggu, paduan suara, semuanya terlibat dalam pelayanan gereja serta pentingnya peranan dokter, 
guru SD, ketua RW/RT, ibu rumah tangga, ahli komputer yang terjun langsung di tengah-tengah masyarakat. Dalam gereja, seluruh anggota jemaat diutus untuk bersaksi melalui perbuatan dan perkataan. Pelayanan sangat berhubungan erat dengan kepedulian dari masing-masing anggota jemaat yang merupakan ketertarikan tulus untuk memperhatikan orang lain. Konsep kepedulian meliputi pertimbangan, empati, pemeliharaan dan cinta, hal ini bukan berarti memberikan toleransi dan tidak memerhatikan hal-hal negatif yang dilakukan, sikap-sikap yang buruk dan ketidakjujuran.

Semangat pelayanan harus terarah kepada kepentingan orang yang dilayani dan tanpa pamrih misalnya melayani orang-orang disekitar yang membutuhkan pertolongan dan bantuan. Pelayanan terhadap sesama dapat diwujudnyatakan jika jemaat Kristen mengasihi Tuhan. Melakukan pelayanan berarti mengikuti jejak Kristus. Sebagai orang yang aktif dalam melakukan pelayanan, setiap jemaat harus meneladani Kristus, terutama dalam menerapkan kehidupan kontemplatif dan aktif. Mereka harus mampu menjalankan setiap pelayanan mereka agar sampai pada tahap kehidupan spiritual di mana mereka mengalami secara nyata bahwa semua yang dilakukan memang ditujukan bagi kemuliaan Allah dan kemajuan pekerjaan misi-Nya. Untuk melakukan pelayanan yang ideal, tidaklah hanya cukup dengan keinginan untuk melayaninamun harus ditunjang dengan spiritualitas misioner yang mendalam. Tanpa hal ini maka dalam melaksanakan pelayanan, setiap jemaat akan cenderung mementingkan ambisi pribadi atau melakukan pelayanan karena faktor kewajiban dan akan dengan mudah meninggalkan pelayanan karena faktor tidak nyaman dan persoalan yang muncul.

Karakter yang dimiliki setiap anggota jemaat dalam menjalankan pelayanan adalah spiritualitas yang utuh dan harus memahami arti dari pelayanan secara utuh. Berbagai kata yang digunakan oleh gereja dengan arti pelayanan diantaranya mengabdi atau menghamba kepada Tuhan dan bukan kepada orang lain. Pola hidup yang bukan lagi hidup untuk diri sendiri melainkan hidup untuk Tuhan dan untuk orang lain. Dorongan untuk melayani Tuhan dan orang lain adalah karena Yesus sendiri sudah melayani umat-Nya. Tujuan hidup-Nya bukanlah untuk mendapatkan pelayanan, melainkan untuk memberi pelayanan. Isi hidup-Nya bukanlah dilayani melainkan melayani. 


\section{KESIMPULAN}

Gereja harus memiliki konsep misi yang holistik untuk menghadapi perkembangan dan perubahan yang terjadi di lingkungan sekitarnya. Tidak dapat dipungkiri bahwa pada saat ini setiap jemaat Kristen diperhadapkan dengan berbagai tantangan dan perubahan yang terjadi di dalam kehidupan masyarakat. Partisipasi jemaat dalam kegiatan pelayanangereja sangat penting untuk diterapkan. Jemaat Kristen yang melakukan pelayanan harus meneladani Kristus terutama dalam menerapkan kehidupan kontemplatif dan aktif serta harus mampu menjalankan setiap pelayanan, karena semua yang dilakukan memang ditujukan bagi kemuliaan Allah dan kemajuan pekerjaan misi-Nya.

Pelaksanaan pelayanan di gereja harus memiliki kaitan atau konteks yang nyata dan relevan dengan kehidupan dan persoalan jemaat dalam kehidupan pribadi dan lingkungan masyarakat. Dalam menjalankan pelayanan, sangat penting bagi jemaat untuk terus mengevaluasi setiap pelayanan yang dikerjakan. Karena seringkali mereka terjebak dalam kondisi pelayanan yang bermotivasi untuk keuntungan diri sendiri. Jemaat tidak akan bisa melakukan pelayanan dengan benar jika mereka tidak mengalami pertumbuhan spiritualitas. Karena spiritualitas yang baik adalah spiritualitas yang bukan hanya sebatas rutinitas saja tetapi juga yang menyatu dengan seluruh aspek kehidupan kita sebagai jemaat Kristen.

Semangat spiritualitas misioner sangat perlu untuk dibangkitkan di antara setiap anggota gereja agar mereka penuh dengan semangat juang yang mendalam untuk menjalankan pelayanan. Spiritualitas misioner berperan penting dalam memberikan motivasi dan juga semangat bagi jemaat dalam melakukan pelayanan. Jemaat diajak untuk semakin menanggapi panggilan Allah yaitu berkarya dalam melakukan pelayanan kepada Tuhan melalui sesamakarena dalam kesehariannya jemaat diperhadapkan dengan dunia yang majemuk bukan hanya dari faktor lingkungan beragama, tetapi juga persoalan yang timbul di lingkungan masyarakat.

Bertitik tolak dari keseluruhan pembahasan yang telah diuraikan, akhirnya penulis mencoba untuk menyampaikan saran yang dapat digunakan untuk meningkatkan semangat pelayanan yang dilandaskan dengan spiritualitas misioner yaitu di dalam gereja perlu untuk dilaksanakan bentuk-bentuk ibadah yang variatif sehingga meningkatkan perhatian dan partisipasi anggota jemaat dalam mengikuti pelayanan bersama di tengahtengah jemaat. Pengembangan setiap metode-metode pelayanan yang 
praktis dan sesuai dengan kebutuhan anggota jemaat dan juga perlu untuk mengatur struktur, program dan inisiatif-inisiatif baru di dalam jemaat agar bisa terlaksana pelayanan ideal sehingga pelayanan yang dilakukan tersebut dapat menjawab kebutuhan rohani anggota jemaat. Peningkatan koordinasi dan sinkronisasi dalam perencanaan, pelaksanaan dan evaluasi program pelayanan itu penting, sehingga dapat dihasilkan suatu capaian realisasi pelaksanaan program pelayanan yang ideal di tengah-tengah jemaat. Sangat perlu dilaksanakan program dan kegiatan dalam merevitalisasi dan meningkatkan kembali komitmen iman jemaat dalam menjalankan pelayanan agar jemaat dapat menjalankan pelayanannya secara berkualitas dan bertanggungjawab. Perlu diterapkan pelaksanaan evaluasi program pelayanan secara teratur, supaya dapat mengendalikan setiap program pelayanan yang dilaksanakan di jemaat. Pelaksanaan program dan kegiatan harus memiliki faktor untuk menjangkau warga jemaat yang selama ini tidak terlibat dalam berbagai program pelayanan yang diadakan oleh gereja, sehingga warga jemaat semakin meningkatkan iman percayanya dan terlibat dalam program pelayanan.

\section{DAFTAR PUSTAKA}

Abineno, J.L. Ch. Diaken. Jakarta: BPK Gunung Mulia, 1994.

Aguado, Maria A. "Mission Spirituality and Care for Creation: An Introduction." International Review of Mission, 2010, 175-79.

Aumann, Jordan. Spiritual Theology. London: Sheed \& Ward, 1980.

Banawiratma, J.B., and Hendri M. Sendjaja. Spiritualitas Dari Berbagai Tradisi. Yogyakarta: Kanisius, 2017.

Bevans, Stephen. "Towards a Mission Spirituality," n.d.

Douglas. Tafsiran Alkitab Masa Kini 3, Matius-Wabyu. Jakarta: Yayasan Komunikasi Bina Kasih, 1982.

Fernando, Ajith. Allah Tritunggal Dan Misi. Jakarta: Yayasan Komunikasi Bina Kasih, 2008.

Go, Piet. Bahan Pengembangan Kerasulan Awam. Jakarta: PT Gramedia, 1994.

Guthrie, Donald. Teologi Perjanjian Baru. Jakarta: BPK Gunung Mulia, 1993.

Heuken, Adolf. Spiritualitas Kristiani. Jakarta: Yayasan Cipta Loka Caraka, 2002. 
Hornby, A. S. Oxford Advanced Learner's Dictionary: International Student's Edition. Oxford: Oxford University, 2010.

"Konferensi Pemimpin Tarekat Religius Indonesia." In Spiritualitas Pelayanan. Jakarta: Hasil Sidang Pleno KOPTARI, 1987.

Martasudjita, Emanuel. Kompendium Tentang Prodiakon. Yogyakarta: Kanisius, 2010.

Milne, B. Mengenali Kebenaran. Jakarta: BPK Gunung Mulia, 2002.

Moleong, Lexi J. Metodologi Penelitian Kualitatif. Bandung: Remaja Karya, 1989.

Olla, Paulinus Yan. Menjadi Saksi Kasih. Yogyakarta: Kanisius, 2008.

Rachmadi, Simon. Reformed Spirituality in Java (Proefschrift). Amsterdam: Vrije Universiteit, 2017.

Ruck, J. Jemaat Misioner. Jakarta: Yayasan Komunikasi Bina Kasih, 2011.

Schneiders, Sandra M. "Spirituality in the Academy." Theological Studies 50, no. 4 (1989): 676-97. https://doi.org/10.1177/00405639890 5000403.

Tampubolon, Yohanes Hasiholan. "Kontekstualisasi Metodologi Misiologi Paulus Dalam Dunia Kontemporer." Excelsis Deo: Jurnal Teologi, Misiologi, Dan Pendidikan 3, no. 2 (December 31, 2019): 13-25. https://doi.org/10.51730/ed.v3i2.13.

- "Misi Gereja Di Era Kapitalisme Global: Eksplorasi Pelayanan Misi Yesus." Societas Dei: Jurnal Agama Dan Masyarakat 7, no. 2 (October 2020): 197-217. https://doi.org/10.33550/sd.v7i2.137.

Tengström, S, and J. Fabry. Theological Dictionary of the Old Testament. Grand Rapids: Eerdmans XIII, 2006.

JULITA ANASTASYA RIEUWPASSA, sedang menyelesaikan program magister di STT Cipanas. 